\title{
Seismic Vulnerability Index for Road Networks
}

\author{
S. ADAFER, M. BENSAIBI
}

Ecole Nationale Supérieure des Travaux Publics -ENSTP-, National School of Built and Ground Works

Engineering, Algiers, Algeria

\begin{abstract}
To prevent heavy damages in road network after a quake, vulnerability studies must be conducted. The framework of the present study aims to develop a vulnerability index (VI) method for roads. The most important parameters influencing the seismic behavior of roads are identified, based on the worldwide seismic feedback experience and data from past Algerian earthquakes (Ain Temouchent 1999 and Zemmouri 2003). A Multi Criterion Decision-Making (MCDM) method is used to derive the relative importance between parameters. The Analytical Hierarchy Process (AHP) allows the determination of weighting factors for each defined parameter. Using the developed model, several examples of roads are processed and the obtained results show a good adequacy with in situ observations.
\end{abstract}

KEYWORD: Earthquake; road; vulnerability assessment; vulnerability index; AHP (Analytical Hierarchy Process)

\section{INTRODUCTION}

Among the main lifelines is road network. It plays a fundamental role in transportation and economic exchanges. Therefore, during major disasters such as earthquakes, it allows emergency and recovery operations.

Past earthquakes showed the vulnerability of road networks under seismic event and highlighted the necessity to assess this vulnerability (Argyroudis et al., 2005), (Yin \& Xu, 2010), (Arsik \& Sibel Salman, 2013).

Several road network vulnerability assessment methods do exist (Berdica \& Eliasson, 2004), (D'Andrea et al., 2006), (Jenelius et al., 2006), (Kiremidjian et al., 2007), (Yin \& Xu, 2010), (Yang \& Qian, 2012) and many methods for performing seismic scenarios were developed (ATC-25, 1991), (FEMA-NIBS, 2004), (RADIUS, 1996), (JICA, 2002), (RISK-UE, 2003), (Werner et al., 2006), (Syner-G D3.7, 2009).

In the present study, a seismic vulnerability assessment of roads is performed using the vulnerability index method. For this purpose, the parameters influencing the seismic vulnerability of roads are identified.

Furthermore, the AHP (Analytical Hierarchy Process) method is used to determine the weighting coefficients of the identified parameters. Finally, the expression of the vulnerability index 'VI' is used to evaluate roads vulnerability and classify them according to their vulnerability.

\section{DEVELOPPED METHOD}

The developed method is based on the vulnerability index method. It allows assessing roads vulnerability on the base of an index resulting from an analytical expression that combines the main parameters influencing the seismic behavior of roads.

The description of the developed method is given here after.

\subsection{Identification of the parameters influencing the vulnerability of roads}

The main parameters are defined on the basis of seismic experience feedback over the world (EERI, 1991), (Erdik, 2000), (JICA, 2002), (FHWA, 2004), (D'Andrea et al., 2006), (Anbazhagan et al., 2011), (Zhang et al., 2012), (Wang \& Zhang, 2013) and Algeria observations following Ain Temouchent and Zemmouri earthquakes (CTTP, 1999), (CTTP, 2003). This leads to distinguish two types of parameters, Structural and Seismic one. Moreover, these parameters are declined in items, factors and categories (Table 1). The aim is to prioritize and to determine a weighting coefficient for each parameter, item and factor. 
Table 1 . Hierarchy of parameters

\begin{tabular}{|c|c|c|c|}
\hline Parameter & Item & Factor & Category \\
\hline \multirow{27}{*}{ Structural } & \multirow{4}{*}{$\begin{array}{l}\text { Pavement } \\
\text { (1) }\end{array}$} & \multirow{2}{*}{$\begin{array}{c}\text { Number of } \\
\text { lanes }\end{array}$} & $>2$ lanes \\
\hline & & & $\leq 2$ lanes \\
\hline & & \multirow{2}{*}{$\begin{array}{l}\text { Pavement } \\
\text { Type }\end{array}$} & Paved \\
\hline & & & Unpaved \\
\hline & \multirow{10}{*}{$\begin{array}{c}\text { Embankment } \\
\text { (2) }\end{array}$} & \multirow{4}{*}{ Height } & $\mathrm{H} \leq 2 \mathrm{~m}$ \\
\hline & & & $2 \mathrm{~m}<\mathrm{H} \leq 5 \mathrm{~m}$ \\
\hline & & & $5 \mathrm{~m}<\mathrm{H} \leq 8 \mathrm{~m}$ \\
\hline & & & $\mathrm{H}>8 \mathrm{~m}$ \\
\hline & & \multirow{3}{*}{$\begin{array}{l}\text { Compaction } \\
\text { quality }\end{array}$} & $\begin{array}{c}\text { Compliant with } \\
\text { standards }\end{array}$ \\
\hline & & & $\begin{array}{c}\text { Compliant with } \\
\text { technical } \\
\text { provisions }\end{array}$ \\
\hline & & & Other \\
\hline & & \multirow{3}{*}{ Slope } & $<2 / 3$ \\
\hline & & & $=2 / 3$ \\
\hline & & & $>2 / 3$ \\
\hline & \multirow{7}{*}{$\begin{array}{l}\text { Ground } \\
\text { conditions } \\
\text { (3) }\end{array}$} & \multirow{4}{*}{ Ground type } & Rock \\
\hline & & & Hard soil \\
\hline & & & Soft soil \\
\hline & & & Very soft soil \\
\hline & & \multirow{3}{*}{$\begin{array}{c}\text { Landslides } \\
\text { potential }\end{array}$} & Low \\
\hline & & & Medium \\
\hline & & & High \\
\hline & \multirow{6}{*}{$\begin{array}{l}\text { Maintenance } \\
\text { conditions } \\
\text { (4) }\end{array}$} & \multirow{3}{*}{$\begin{array}{l}\text { Pavement } \\
\text { conditions }\end{array}$} & High \\
\hline & & & Medium \\
\hline & & & Low \\
\hline & & \multirow{3}{*}{$\begin{array}{l}\text { Slope } \\
\text { protection } \\
\text { measures }\end{array}$} & $\begin{array}{c}\text { Compliant with } \\
\text { standards }\end{array}$ \\
\hline & & & $\begin{array}{c}\text { Compliant with } \\
\text { technical } \\
\text { provisions }\end{array}$ \\
\hline & & & $\begin{array}{l}\text { Without any } \\
\text { protections }\end{array}$ \\
\hline \multirow{7}{*}{ Hazard } & \multirow{5}{*}{$\begin{array}{c}\text { Seismic } \\
\text { intensity (5) }\end{array}$} & \multirow{5}{*}{-} & $\mathrm{C} 1 *$ \\
\hline & & & $\mathrm{C} 2 *$ \\
\hline & & & $\mathrm{C} 3 *$ \\
\hline & & & $\mathrm{C} 4 *$ \\
\hline & & & $\mathrm{C} 5 *$ \\
\hline & \multirow{2}{*}{$\begin{array}{l}\text { Liquefaction } \\
\text { potential (6) }\end{array}$} & \multirow{2}{*}{ - } & $0 \leq \mathrm{PL}<5$ \\
\hline & & & $5 \leq \mathrm{PL}<15$ \\
\hline
\end{tabular}

* With: C1: MMI < VIII, C2: VIII $\leq \mathrm{MMI}<\mathrm{IX}, \mathrm{C} 3$ : $\mathrm{IX} \leq \mathrm{MMI}<\mathrm{X}$, $\mathrm{C} 4: \mathrm{X} \leq \mathrm{MMI}<\mathrm{XI}$ and $\mathrm{C} 5$ : $\mathrm{XI} \leq \mathrm{MMI}$.

\subsection{Quantification of the identified parameters}

The AHP method (Saaty, 1980) is used to take into account the relative contribution of each parameter (Adafer \& Bensaibi, 2014). For each level of the hierarchy, pairwise comparisons are carried out. These binary comparisons allow constructing matrices that are used to obtain criterions weighting coefficients. The obtained weights for each level (parameters, items and factors) are given in Table 2.

Table 2. Weighting factors

\begin{tabular}{|c|c|c|c|c|c|}
\hline Parameter & $\mathrm{W}^{*}$ & Item & $\mathrm{W}^{*}$ & Factor & $\mathrm{W}^{*}$ \\
\hline \multirow{9}{*}{ Structural } & \multirow{9}{*}{0.250} & \multirow{2}{*}{ (1) } & \multirow{2}{*}{0.108} & Number of lanes & 0.667 \\
\hline & & & & Pavement Type & 0.333 \\
\hline & & \multirow{3}{*}{ (2) } & \multirow{3}{*}{0.283} & Height & 0.648 \\
\hline & & & & Compaction quality & 0.122 \\
\hline & & & & Slope & 0.230 \\
\hline & & \multirow{2}{*}{ (3) } & \multirow{2}{*}{0.561} & Ground type & 0.200 \\
\hline & & & & Landslides potential & 0.800 \\
\hline & & \multirow{2}{*}{ (4) } & \multirow{2}{*}{0.048} & $\begin{array}{l}\text { Pavement } \\
\text { conditions }\end{array}$ & 0.667 \\
\hline & & & & $\begin{array}{c}\text { Slope protection } \\
\text { measures }\end{array}$ & 0.333 \\
\hline \multirow{3}{*}{ Hazard } & \multirow{3}{*}{0.750} & (5) & 0.633 & - & - \\
\hline & & (6) & 0.106 & - & - \\
\hline & & (7) & 0.261 & - & - \\
\hline
\end{tabular}

*Weight.

\subsection{Determination of vulnerability index}

Based on the feedback from past earthquakes, experts assigned a score to each category as given in Table 3. Then using the weighting coefficients (Table 2) and the assigned scores (Table 3), the vulnerability index VI is calculated using the following formula (Adafer \& Bensaibi, 2014):

$$
V I=\sum_{i=1}^{2} W_{i} \sum_{j=1}^{3 \text { or } 4} W_{i j} \sum_{k=1}^{2 o r 3} W_{i j k} C_{i j k l}
$$

Where:

$\mathrm{W}_{\mathrm{i}}$ the weighting coefficient of structural or hazard parameters,

$\mathrm{W}_{\mathrm{ij}}$ the weighting coefficient of items,

$\mathrm{W}_{\mathrm{ijk}}$ the weighting coefficient of factors, where

$\mathrm{W}_{\mathrm{ijk}}=1$ if $\mathrm{i}=2$

and

$\mathrm{C}_{\mathrm{ijk} \mathrm{l}}$ the score of category, where $1=2$ or 3 or 4 or 5 . 
Table 3. Assigned scores

\begin{tabular}{|c|c|c|c|}
\hline Parameter & Factor & Category & Scores \\
\hline \multirow{27}{*}{ Structural } & \multirow{2}{*}{$\begin{array}{l}\text { Number } \\
\text { of lanes }\end{array}$} & $>2$ lanes & 20 \\
\hline & & $\leq 2$ lanes & 40 \\
\hline & \multirow{2}{*}{$\begin{array}{l}\text { Pavement } \\
\text { Type }\end{array}$} & Paved & 20 \\
\hline & & Unpaved & 50 \\
\hline & \multirow{4}{*}{ Height } & $\mathrm{H} \leq 2 \mathrm{~m}$ & 10 \\
\hline & & $2 \mathrm{~m}<\mathrm{H} \leq 5 \mathrm{~m}$ & 30 \\
\hline & & $5 \mathrm{~m}<\mathrm{H} \leq 8 \mathrm{~m}$ & 40 \\
\hline & & $\mathrm{H}>8 \mathrm{~m}$ & 50 \\
\hline & \multirow{3}{*}{$\begin{array}{l}\text { Compactio } \\
\text { n quality }\end{array}$} & Compliant with standards & 10 \\
\hline & & $\begin{array}{l}\text { Compliant with technical } \\
\text { provisions }\end{array}$ & 30 \\
\hline & & Other & 40 \\
\hline & \multirow{3}{*}{ Slope } & $<2 / 3$ & 10 \\
\hline & & $=2 / 3$ & 30 \\
\hline & & $>2 / 3$ & 50 \\
\hline & \multirow{4}{*}{$\begin{array}{l}\text { Ground } \\
\text { type }\end{array}$} & Rock & 0 \\
\hline & & Hard soil & 10 \\
\hline & & Soft soil & 40 \\
\hline & & Very soft soil & 50 \\
\hline & \multirow{3}{*}{$\begin{array}{l}\text { Landslides } \\
\text { potential }\end{array}$} & Low & 10 \\
\hline & & Medium & 30 \\
\hline & & High & 50 \\
\hline & \multirow{3}{*}{$\begin{array}{l}\text { Pavement } \\
\text { conditions }\end{array}$} & High & 10 \\
\hline & & Medium & 20 \\
\hline & & Low & 40 \\
\hline & \multirow{3}{*}{$\begin{array}{l}\text { Slope } \\
\text { protection } \\
\text { measures }\end{array}$} & Compliant with standards & 20 \\
\hline & & $\begin{array}{l}\text { Compliant with technical } \\
\text { provisions }\end{array}$ & 30 \\
\hline & & Without any protections & 50 \\
\hline \multirow{10}{*}{ Hazard } & \multirow{5}{*}{-} & MMI < VIII & 10 \\
\hline & & $\mathrm{VIII} \leq \mathrm{MMI}<\mathrm{IX}$ & 20 \\
\hline & & $\mathrm{IX} \leq \mathrm{MMI}<\mathrm{X}$ & 30 \\
\hline & & $\mathrm{X} \leq \mathrm{MMI}<\mathrm{XI}$ & 40 \\
\hline & & $\mathrm{XI} \leq \mathrm{MMI}$ & 50 \\
\hline & \multirow{3}{*}{-} & $0 \leq \mathrm{PL}<5$ & 10 \\
\hline & & $5 \leq \mathrm{PL}<15$ & 30 \\
\hline & & $15<\mathrm{PL}$ & 50 \\
\hline & \multirow{2}{*}{-} & No intersection & 10 \\
\hline & & Intersection & 40 \\
\hline
\end{tabular}

\section{STUDIED CASES}

Three case studies have been treated. The studied roads are located in the town of Ain Temouchent (West Algiers). On 22 December 1999 an earthquake $(\mathrm{MMI}=\mathrm{VII})$ occurred and damaged these roads.

\subsection{Case study 1:}

This case study is related to a national road section (RN35) located at Ain Temouchent at the kilometer marker 5+500. This road links Ain Temounchent to Tlemcen a big City in the North-West of Algeria. This road section crosses a soft soil and contains a low embankment $(\mathrm{H}=2 \mathrm{~m})$.

The obtained vulnerability index (VI) using equation 1 is equal to 12.22 .

\subsection{Case study 2:}

This case study is related to a national road section (RN35) located at Ain Temouchent at the kilometer marker 5+900. This road section crosses a soft soil and contains a high embankment $(\mathrm{H}=10 \mathrm{~m})$.

The obtained vulnerability index (VI) using equation 1 is equal to 14.45 .

\subsection{Case study 3:}

This case study is related to a national road section (RN35) located in the suburb of Ain Temouchent at the kilometer marker $20+850$. This road section crosses a soft soil and contains a high embankment $(\mathrm{H}=7 \mathrm{~m})$.

The obtained vulnerability index (VI) using equation 1 is equal to 13.59 .

\subsection{Discussion :}

As it can be noticed the second value of the VI is greater than the other values, thus road section 2 is more vulnerable. This is due to the height of embankment, the quality of embankment compaction materials and the lack of slope protection measures. Furthermore, the pavement conditions are poorly than in the case study 1 and 3 . The road section 1 is the least vulnerable.

The results of this study are in a good adequacy with in-situ observations. In fact, road section 2 suffered significant damages and great retrofitting activities were necessary after the quake (CTTP, 1999).

\section{CONCLUSION}

The developed method is used to calculate a vulnerability index for road networks. This index 
allows classifying roads according their seismic vulnerability and prioritizing retrofitting activities. Therefore, this method can be used as a diagnosis tool. The developed method is well-adapted to emergency management and urban planning.

\section{REFERENCES}

[1] Adafer, S. \& Bensaibi, M. 2014. Seismic vulnerability assessment of road networks. Second European Conference on Earthquake Engeneering and Seismology. Turkey, Istanbul, Aug 25-29.

[2] Anbazhagan, P. et al. 2011. Classification of road damage due to earthquakes. Natural Hazards, 60(2), 425-460.

[3] Argyroudis, S. A. et al. 2005. Roadway Network Seismic Risk Analysis in Urban Areas : The case of Thessaloniki Greece. Paper presented at the Geoline, Lyon, France.

[4] Arsik, I. \& Sibel Salman, F. 2013. Modeling Earthquake Vulnerability of Highway Networks. Electronic Notes in Discrete Mathematics 41 (1), 319-326.

[5] ATC-25. 1991. Seismic Vulnerability and Impact of Disruption of Lifelines in the Conterminous United States, Applied Technology Council. USA.

[6] Berdica, K. \& Eliasson, J. 2004. Regional accessibility analysis from a vulnerability perspective. $2^{\text {nd }}$ International Symposium on Transportation Network Reliability, 89-95.

[7] CTTP. 1999. Road networks expertise of Ain Temouchent following the earthquake of 22/12/99. Algeria.

[8] CTTP. 2003. Road networks diagnosis of Boumedes following the earthquake of 21/05/2003. Algeria.

[9] D'Andrea, A. et al. 2006. Valutazione del rischio sismico di infrastrutture viarie urbane: analisi funzionale della rete in condizioni di emergenza. AIPCR - Comitato Nazionale Italiano - XXV Convegno Nazionale Stradale,Napoli, Italy,4-7 ottobre.

[10] EERI. 1991. Costa Rica Earthquake of april 22, 19991. EERI Special earthquake report,USA.

[11] Erdik, M. 2000. Report on 1999 Kocaeli and Duzce (Turkey) earthquakes. University, Dept. of Earthquake Engineering, Istanbul, Turkey.

[12] FEMA-NIBS. 2004. Hazard US Earthquake Loss Estimation Methodology. National Institute of Building Sciences. NIBS document 5200-03, Washington, DC.
[13] FHWA. 2004. Seismic Retrofitting Manual for Highway Structures. Federal Highway Administration Part 2, US Departement of transportation, USA.

[14] Jenelius, E. et al. 2006. Importance and exposure in road network vulnerability. Transportation Research part A: Policy and Practice, 40(7), 537-560.

[15] JICA. 2002. The study on earthquake disaster mitigation in the Kathmandu Valley. Nippon Koei Co LTD,Final report,Kingdom of Nepal.

[16] Kiremidjian, A. et al. 2007. Seismic Risk Assessment of Transportation Network Systems. Journal of Earthquake Engineering 1(3), 1-12.

[17] RADIUS. 1996. Assessment Tools for Diagnostic of Urban Areas against Seismic Disasters. Secrétariat IDNDR (International Decade for Natural Disaster Reduction), United Nations

[18] RISK-UE. 2003. Vulnerability assessment of lifelines and essential facilities (WP06): methodological handbook Appendix 1:Roadway transportation system. Report $\mathrm{n}^{\circ}$ GTR-RSK 0101-152av7/Geo Ter, UE.

[19] Saaty, T. L. 1980. The analytic hierarchy processess : planning, priority setting resource. Mc Grew, Hill, New York.

[20] Syner-G D3.7. 2009. Systemic Seismic Vulnerability and Risk Analysis for Buildings, Lifeline Networks and Infrastructures Safety Gain, . Norwegian Geotechnical Institute (NGI) - Seventh Framework Programme,UE

[21] Wang, Z. Z. \& Zhang, Z. 2013. Seismic damage classification and risk assessment of mountain tunnels with a validation for the 2008 Wenchuan earthquake. Soil Dynamics and Earthquake Engineering, 45, 45-55.

[22] Werner, S. D. et al. 2006. Use of Seismic Risk Analysis of Roadway Systems to Facilitate Performance-Based Engineering and Risk-Reduction Decision Making. Multidisciplinary Center for Earthquake Engineering Research.

[23] Yang, L. \& Qian, D. 2012. Vulnerability Analysis of Road Networks. Journal of transportation systems engeneering and information technology, 12 (1), 105.

[24] Yin, H. \& Xu, L. 2010. Measuring the structural vulnerability of road network : A network efficiency perspective. J.Shanghai Jiaotong University and Springer-Verlag Berlin Heidelberg, 15(6), 736-742.

[25] Zhang, J. et al. 2012. Seismic damage of earth structures of road engineering in the 2008 Wenchuan earthquake. Environmental Earth Sciences, 65(4), 987-993. 